\title{
Correction to: The Social Dimensions of Fiction
}

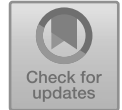

\section{Steven Tötösy de Zepetnek}

The author name is incorrectly captured in all chapters of this book. The correct author is Steven Tötösy de Zepetnek. This has been corrected.

The updated online version of the original book can be found at https://doi.org/10.1007/978-3-663-13909-6.

S. Tötösy de Zepetnek, The Social Dimensions of Fiction, DOI 10.1007/978-3-663-13909-6_7, (C) Springer Fachmedien Wiesbaden, 2019 